\title{
Editorial
}

\section{Endings and Beginnings}

"[Everything] has to come to an end, sometime."

\section{Frank Baum \\ The Marvelous Land of $\mathrm{Oz}(1904)^{1}$}

As our regular readers know, this is a very special issue of College $\mathcal{E}$ Research Libraries. It is the last one that we will print. Beginning with the first issue of volume 75 (January 2014), this journal will join many others in being published solely in digital form. The road to this decision has been explained before, and CERL readers are well-informed regarding the seismic changes currently re-shaping academic publishing and the broader system of scholarly communication. $C \mathcal{E} R L$ will not be the first scholarly journal to move to a digital-only publishing model, and it will not be the first to embrace open access publishing, but it is still unusual to see a journal with the history and reputation that $C \mathcal{E} R L$ enjoys dive into the future of scholarly publishing with both feet. We know it was an unusual decision because of the number of scholarly associations that have contacted us to discuss our decision-making process, and we know it was the right decision because of the work that the Association of College \& Research Libraries has done over the past decade to explore best practices in open access publishing and to contribute to the future of scholarly communications.

It has been six years since the Association advanced its "Research Agenda for Scholarly Communication," which included the call to promote research in areas such as authorship, value metrics, and the adoption of successful innovations. ${ }^{2}$ As a print publication, $C E R L$ provided a venue for disseminating the results of such research, including Malenfant's study of scholarly communications services as an emergent component of the core responsibilities of liaison librarians, Nariani and Fernadez's study of the factors influencing authors' decisions to publish (or to avoid publishing) in open access journals, and Walters and Linvill's study of the characteristics of open ac-

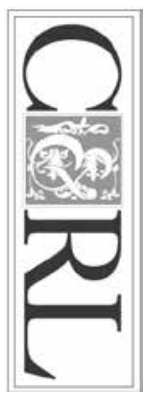
cess journals. ${ }^{3}$ Most recently, a study by Ramirez et. al. of the connections (perceived and actual) between the decision to publish an electronic thesis or dissertation (ETD) in an open access repository and the impact of that decision on the potential for later publication in a traditional format became part of a broader discussion in the higher education press. ${ }^{4}$ In short order (as these things go), CERL has moved from subscription access to open access, has collaborated with library partners to provide open access to its complete digital backfile, and is poised to move from a publication model still bound to the limitations of print to one that can fully embrace the opportunities provided by the Web as publishing platform. Beginning in January, College \& Research Libraries will not only be a leading site for the dissemination of research furthering the Association's scholarly communications agenda, it will be one of the successful innovations studied as part of that research.

And even after years of effort, it is clear that this research must still be pursued. As the editor of an open-access, peerreviewed journal, I am a member of a community still addressing the charges laid at our feet by the "OA sting" reported last month in Science. ${ }^{5}$ The specifics of that study are now well known, as are the significant limitations of its research design and what its conclusions actually suggest about open access, peer review, and the future of scholarly communications. ${ }^{6}$ The complex nature of such research was demonstrated in a separate study, also published last month, ironically, in the open-access PLOS Biology. ${ }^{7}$ It is appropriate, then, to find that this final issue 
of our print journal includes a study of peer reviewers and their role in ensuring the integrity of the scholarly communications process.

Currently, there are over 100 peer reviewers engaged in the evaluation and improvement of manuscripts submitted to College $\mathcal{E}$ Research Libraries. The end of subscription-access publishing at CERL did not affect their role in the production of this journal; indeed, it may have enhanced it, as our principled decision to embrace open access ensured the ongoing engagement of peer reviewers committed to the integrity of that publishing model. The end of our print run will not affect our commitment to publishing research studies of the highest quality; indeed, it will ensure that this commitment carries forward into the uncertain (but exciting) future of scholarly publishing.
Everything comes to an end, and for the print version of College $\mathcal{E}$ Research Libraries that end comes today. But every ending also brings a new beginning, and we look forward to making that beginning with our readers in 2014. This will be an exciting year for the journal, as we continue to serve as a test-bed for innovation in scholarly communication, including an exploration of open peer review as a complementary approach to our established peer-review process. ${ }^{8}$ We will embrace new opportunities to amplify the research results reported in our journal through social media platforms and opportunities to make connections across the wider ACRL publishing and professional development programs. Thank you to all the authors and readers who have made this a leading journal in academic librarianship for 74 years; we look forward to seeing you, online, for the $75^{\text {th }}$.

Scott Walter DePaul University

\section{Notes}

1. L. Frank Baum, The Marvelous Land of Oz: A Sequel to the Wizard of Oz (Chicago: Reilly \& Lee Co., 1904), 58, accessed October 17, 2013, http://books.google.com/books?id=HXKK6DuC-DMC.

2. ACRL Scholarly Communications Committee, "Establishing a Research Agenda for Scholarly Communication: A Call for Community Engagement," Association of College \& Research Libraries (2006), accessed October 17, 2013, http://www.ala.org/acrl/sites/ala.org.acrl/files/content/ issues/scholcomm/SCResearchAgenda.pdf.

3. Kara J. Malenfant, "Leading Change in the System of Scholarly Communication: A Case Study of Engaging Liaison Librarians for Outreach to Faculty," College \& Research Libraries 71 (2010): 63-76, accessed October 17, 2013, http://crl.acrl.org/content/71/1/63.full.pdf+html; Rajiv Nariani and Leila Fernandez, "Open Access Publishing: What Authors Want," College \& Research Libraries 73 (2012): 182195, accessed October 17, 2013, http://crl.acrl.org/content/73/2/182.full.pdf+html; William H. Walters and Anne C. Linvill, "Characteristics of Open Access Journals in Six Subject Areas," College \& Research Libraries 72 (2011): 372-392, accessed October 17, 2013, http://crl.acrl.org/content/72/4/372.full.pdf+html

4. Marisa L. Ramirez et al., "Do Open Access Electronic Theses and Dissertations Diminish Publishing Opportunities in the Social Sciences and Humanities?: Findings from a 2011 Survey of Academic Publishers," College \& Research Libraries 74 (2013): 368-380, accessed October 17, 2013, http://crl.acrl.org/content/74/4/368.full.pdf+html; Stacey Patton, "Embargoes Can Only Go So Far to Help New Ph.D.s Get Published, Experts Say," Chronicle of Higher Education, July 30, 2013, accessed October 17, 2013, http://chronicle.com/article/Embargoes-Can-Go-Only-So-Far/140603/.

5. John Bohannon, "Who's Afraid of Peer Review?," Science 342, no. 6154 (2013): 60-65, accessed October 17, 2013, doi:10.1126/science.342.6154.60.

6. Paul Basken, "Critics Say Sting on Open-Access Journals Misses Larger Point," Chronicle of Higher Education, October 4, 2013, accessed October 17, 2013, http://chronicle.com/blogs/percolator/ critics-say-sting-on-open-access-journals-misses-larger-point; Barbara Fister, "The Sting," Inside Higher Ed, October 10, 2013, accessed October 17, 2013, http://www.insidehighered.com/blogs/ library-babel-fish/sting; Barbara Fister, "Judging Journals," Inside Higher Ed, October 17, 2013, accessed October 18, 2013, http://www.insidehighered.com//blogs/library-babel-fish/judging-journals.

7. Adam Eyre-Walker and Nina Stoletzki, "The Assessment of Science: The Relative Merits of Post-Publication Review, the Impact Factor, and the Number of Citations," PLOS Biology 11, no. 10 (2013): e1001675, accessed October 17, 2013, doi:10.1371/journal.pbio.1001675.

8. Emily Ford, "Defining and Characterizing Open Peer Review: A Review of the Literature," Journal of Scholarly Publishing 44 (2013), accessed October 17, 2013, http://muse.jhu.edu/journals/ journal_of_scholarly_publishing/v044/44.4.ford.html. 